\title{
PENGARUH TERAPI BERMAIN TERHADAP KEMAMPUAN MOTORIK HALUS ANAK DOWN SYNDROMEDI SLB YPPLB PADANG
}

\author{
Diana Arianti ${ }^{1}$, Andita Elsa Fitri ${ }^{2}$ \\ ${ }^{1}$ Sekolah Tinggi Ilmu Kesehatan Alifah, Padang 25000 \\ Email: dianaarianti84@gmail.com \\ ${ }^{1}$ STIKes Alifah, Padang 25000 \\ Email: Anditaelsa@gmail.com
}

\begin{abstract}
ABSTRAK
Kelahiran anak Down Syndrom di Amerika Serikat kurang lebih 4.000 anak dilahirkan setiap tahunnya. MenurutIndonesia Centre For Biodiversity dan Biotechnology (ICBB) Bogor , terdapat lebih dari 300 ribu anak pengidap Down Syndrom di Indonesia. Umumnya anak Down Syndrom usia sekolah masih mengalami keterlambatan kemampuan motorik dan kesulitan melakukan koordinasi antara mata dan tangan. Salah satu terapi yang diberikan untuk meningkatkan kemampuan motorik halus anak Down Syndrom yaitu terapi bermain meremas adonan. Tujuan penelitian ini adalah untuk melihat pengaruh terapi bermain terhadap kemampuan motorik halus anak Down Syndrom. Jenis penelitian Pre-Eksperimental Design dengan rancanganOne Group Pretest-Posttest Design. Penelitian dilakukan di SLB YPPLB Padang tanggal 08 Mei s/d 28 Mei 2016 sebanyak 12 kali pertemuan dengan metode meremas adonan. Populasi penelitian anak Down Syndrom usia 6-12 tahun. Jumlah sampel 13 orang dengan teknik sampling jenuh. Pengolahan data secara komputerisasi dengan uji wilcoxon. Hasil penelitian didapatkan rerata kemampuan motorik halus sebelum diberikan terapi bermain 5,08 dan sesudah diberikan terapi bermain 12,46. Hasil uji statistik didapatkan nilai $\mathrm{P}=0,002$, dimana terdapat pengaruh terapi bermain terhadap kemampuan motorik halus anak Down Syndrom. Berdasarkan hasil penelitian disarankan instansi pendidikan untuk lebih mengupayakan sarana alat-alat terapi bermain, latihan terus menerus 3 kali dalam seminggu selama \pm 15 menit untuk meningkatkan kemampuan motorik halus anak Down Syndrom dan pemberdayaan keluarga untuk meningkatkan kemampuan motorik halus anak Down Syndrom dengan latihan terapi bermain dirumah.
\end{abstract}

\section{Kata Kunci, Terapi Bermain, Kemampuan Motorik Halus, Down Syndrom,}

\section{ABSTRACT}

Down Syndrome births is approximately 4000 children each year in the United States. According to the Indonesia Centre for Biodiversity and Biotechnology (ICBB) Bogor, there are more than 300 thousand children with Down Syndrome in Indonesia. Generally, there are still tardiness in motor skill and coordination difficulty between the eyes and the hand in school-age children with Down Syndrome. One of the therapies that can be given to improve the fine motor skill of Down Syndrome children is the play therapy of kneading dough. The purpose of this research is to see the effect of the play therapy to the fine motor skill of Down Syndrome children. The kind of this research is PreExperimental Design with One Group Pretest-Posttest Design. This research is carried out in SLB YPPLB Padang on May $8^{\text {th }}-28^{\text {th }}$, 2016 with 12 meetings with the method of kneading dough. The research population of Down Syndrome children aged 6 - 12 years. There are 13 people as the sample using saturated sampling technique. The data processing is computerized using Wilcoxon test. The result of the research shows that the average of the fine motor skill before the play therapy is 5.08 and after the play therapy is 12.46 . The result of statistic test obtains the value of $P=0.002$, which shows that there is effect of the play therapy to the fine motor skill of Down Syndrome children. According to the result of this research, it can be suggested for the educational institution to further develop the play therapy tools, continuous exercise 
three times a week for approximately 15 minutes to improve the fine motor skill of Down Syndrome children and empowering family to improve the fine motor skill of Down Syndrome children by the play therapy at home.

\section{Keywords: The Play Therapy, Fine Motor Skill, Down Syndrome.}

\section{PENDAHULUAN}

Tumbuh kembang anak berlangsung secara teratur, saling berkaitan dan berkesinambungan sejak awal konsepsi sampai dewasa, usia sekolah anak mulai membangun prilaku yang sehat, belajar keterampilan fisik, keterampilan motorik meningkat dan mengembangkan keterampilan dasar seperti menulis, membaca dan berhitung (Supartini, 2004 dalam Robert 2009). Anak usia sekolah (6-12 tahun), mengalami perkembangan yang relatif stabil dibandingkan anak usia pra sekolah. Anak usia sekolah mengalami peningkatan kognitif dan meningkatnya kemampuan motorik halus seperti melakukan koordinasi gerakan tangan dengan otak (Soetjiningsih, 2013).

Setiap tahapan perkembangan anak terdapat beberapa aspek perkembangan yang tumbuh secara kompleks, memiliki karakteristik yang berbeda sesuia tahapan usianya masing-masing (Papalia, Olds \& Fieldman, 2008), dengan tuntutan dan tanggung jawab yang berbeda. Anak usia sekolah dituntut untuk mampu memenuhi kompetensi secara akademis, sosial, motorik dan intelektual.

Tiap-tiap tahap perkembangan memiliki potensi gangguan perkembangan yang berbeda tergantung pada fase perkembangan yang dialami setiap anak. Pada anak usia sekolah gangguan perkembangan yang mungkin terjadi yaitu gagal sekolah, gangguan perkembangan koordinasi, retardasi mental, gangguan bicara dan bahasa (Fadhli, 2010). Salah satu gangguan perkembangan tersebut adalah Down Syndrom. Down Syndrome terjadi karena kelainan kromosom, yaitu (trisomy 21) akibat kegagalan sepasang kromosom untuk saling memisahkan diri saat terjadi pembelahan (Fadhli, 2010).

Umumnya anak Down Syndrom usia sekolah masih mengalami keterlambatan dalam hal kemampuan motorik, dimana gangguan yang sering terjadi salah satunya yaitu kemampuan menulis. Anak Down Syndrom pada usia ini masih kesulitan melakukan koordinasi antara mata dan tangan serta kurangnya kemampuan ketangkasan jari-jemari. Hal ini disebabkan karena sebagian besar anak Down Syndrom memiliki kekuatan otot yang lemah bila dibandingkan dengan anak normal (Gunarhadi, 2005).

Data statistik menunjukkan bahwa di antara wanita yang berusia 20 tahun, 1 dari 2.300 melahirkan anak dengan Down Syndrom. Pada wanita berusia 30 hingga 34 tahun, insidensi Down Syndrome 1 dari 750 kelahiran. Sedangkan pada wanita berusia 39 tahun, insidensi itu naik secara drastis sampai 1 dari 280 kelahiran. Pada wanita berusia lebih dari 45 tahun, insidensi Down Syndrome 1 dari 65 kelahiran (Situmorang, 2011).

Fadhli (2010) menyatakan bahwa angka kejadian Down Syndrome rata-rata di seluruh dunia adalah 1 pada setiap 700 kelahiran. Kejadian ini akan bertambah dengan semakin tuanya usia ibu hamil. Biasanya caloncalon bayi Down Syndrome 60\% cenderung akan gugur dan $20 \%$ akan lahir mati. Di Amerika Serikat kurang lebih 4.000 anak dilahirkan dengan Down Syndrome setiap tahunnya, atau sekitar 1 dari 800-1000 kelahiran hidup.

Di Indonesia sendiri, sebagaimana negara berkembang lainnya, kelainan ini belum mendapat cukup perhatian. Menurut catatan Indonesia Centre for Biodiversity dan Biotechnology (ICBB) Bogor, di Indonesia terdapat lebih dari 300 ribu anak pengidap Down Syndrome. Meskipun orang tua dari segala usia mempunyai kemungkinan untuk mendapat anak yang menderita Down Syndrome, tetapi kemungkinannya lebih besar untuk ibu yang usianya di atas 35 tahun (Aryanto,2008).

Indonesia dengan sekitar 5 juta kelahiran hidup, maka akan dijumpai sekitar 5000 kasus baru Down Syndrom setiap tahunnya. Keadaan ini dapat menjadi masalah besar dalam bidang kesehatan, pendidikan, lapangan kerja, maupun pendanaan yang dibutuhkan untuk menanggulangi masalah tersebut. Secara statistik ditemukan lebih banyak dilahirkan oleh ibu yang berusia lebih dari 30 tahun dan juga jarang ditemukan pada bayi yang dilahirkan oleh ibu yang masih muda (Malino, 2013).

Berdasarkan data dari Dinas Pendidikan Provinsi Sumatera Barat menyatakan bahwa di Sumatera Barat sendiri belum ada data resmi tentang penderita anak Down Syndrome, dikarenakan kehadiran anak Down Syndrome tidak menetap tiap semester. Jumlah SLB yang ada di Sumatera Barat tahun 2013-2014 sebanyak 126 sekolah, tahun 2014-2015 sebanyak 127 sekolah. Dari hasil penelusuran jumlah penyandang Down Syndrome di sekolah luar biasa dari 13 sekolah yang menangani masalah Down Syndrome pada anak terdapat jumlah penderita Down Syndrome yang ditangani di sekolah tersebut berjumlah 209 orang. Jumlah tersebut belum termasuk penyandang Down Syndrome yang belum diketahui oleh Dinas Pendidikan.

Di kota Padang sendiri, pada tahun 2013-2014 terdapat 36 SLB yang menangani anak berkebutuhan 
khusus. Tahun 2014-2015 sebanyak 37 SLB yang menangani anak berkebutuhan khusus. Dimana tercatat jumlah anak berkebutuhan khusus sebanyak 761 orang untuk tingkat SD dan 151 orang untuk tingkat SMP dari 37 SLB yang ada dikota Padang yang terdiri dari lakilaki dan perempuan.

Penanganan Down Syndrome dapat dilakukan dengan beberapa cara seperti latihan otot untuk melatih kelemahan otot, latihan dasar terpusat, latihan kombinasi untuk perkembangan fisik, konsultasi ke seorang ahli seperti dokter anak, ahli jiwa, atau ahli fisioterapi dan memberikan terapi (Fadhli, 2010). Jenisjenis terapi yang dapat diberikan untuk anak Down Syndrome Yaitu: Terapi Fisik (Physio Theraphy), terapi okupasi, terapi remedial, terapi sensori integrasi, terapi perilaku, terapi akupuntur, terapi musik, terapi lumbalumba, terapi craniosacral,terapi wicara, dan terapi bermain (ISDI, 2008) di dalam (Nasution, 2011).

Terapi bermain adalah usaha mengubah tingkah laku bermasalah dengan menempatkan anak dalam situasi bermain (Adriana, 2011). Bermain merupakan cerminan kemampuan fisik, intelektual, emosional, dan sosial. Bermain merupakan media yang baik untuk belajar karena dengan bermain anak-anak akan berkatakata (berkomunikasi), belajar menyesuaikan diri dengan lingkungan, mengenal waktu, jarak serta suara (Wong, 2008)

Salah satu jenis terapi bermain yang diberikan pada anak Down Syndrom adalah jenis permainan edukatif. Permainan edukatif merupakan alat permainan yang dapat memberikan fungsi permainan secara optimal dan perkembangan anak, dimana melalui alat permainan ini anak akan selalu dapat mengembangkan kemampuan fisiknya, bahasa, kemampuan kognitif, dan adaptasi sosialnya ( Soetjiningsih, 2013 ).

Hasil analisis Budiman (2008) dilapangan didapatkan hasil bahwa reaksi kemampuan motorik anak Down Syndrome sebelum diberikan alat permainan edukatif (APE) pada kelompok pre-test seluruh anak tidak mampu melakukan permainan sesuai tahap kriteria bermain yang ditentukan dan pada kelompok post-test hanya $70 \%$ yang mampu melakukan permainan.

Hasil penelitian Dekayati (2014) menunjukkan kemampuan motorik anak Down Syndrom sebelum diberikan intervensi terapi bermain menyusun menara donat, 21 anak (70 \%) tidak mampu dan 9 anak (30\%) anak mampu menyusun menara donat. Kemudian setelah diberikan intervensi hasil meningkat sebanyak 14 anak $(46,7 \%)$ tidak mampu menyusun menara donat dan 16 anak $(53,3 \%)$ anak mampu menyusun menara donat.

Dalam hal ini perawat berperan sebagai pendidik, dimana perawat membantu anak mencapai dan mempertahankan tingkat kesehatan dan fungsi optimum seumur hidup dalam rentang kapasitas mereka serta perawat membantu menstimulasi perkembangan motorik halus anak Down Syndrom bagi penyesuian sosial dan prilakunya (Nevid \& dkk, 2005).

Berdasarkan survey awal yang dilakukan oleh peneliti di SLB YPPLB Padang pada tanggal 14 Januari 2016, didapatkan data jumlah siswa yang menderita Down Syndrome pada tahun ajaran 2015-2016 sebanyak 22 orang untuk tingkat SDLB, SMPLB, dan SMALB yang terdiri dari 16 orang laki-laki dan 6 orang perempuan. Untuk anak Down Syndrom Usia Sekolah Sebanyak 13 Orang yang terdiri dari 8 orang laki-laki dan 5 orang perempuan (Data siswa baru SLB YPPLB Padang tahun 2015-2016).

Berdasarkan hasil wawancara yang dilakukan peneliti dengan guru di SLB YPPLB Padang pada tanggal 14 Januari 2016 mengatakan, anak Down Syndrom yang ada di SLB tersebut masih kesulitan dalam menulis salah satunya dalam hal menulis angka 1-10 dan mereka juga kesulitan mengangkat tangan, serta mereka kesulitan untuk menggerakkan jarijemarinya dalam memegang benda seperti pensil, balok, dan krayon mereka lebih sering diam dan tertawa.

Selama peneliti melakukan observasi di SLB YPPLB tersebut, anak Down Syndrom yang ada di SLB tersebut masih kesulitan dalam memegang pensil untuk menulis dan menggerakkan pergelangan tangannya ke atas dan kebawah, ke kiri dan ke kanan untuk menulis. Dari 7 anak yang di observasi, 4 (57\%) anak belum bisa menulis huruf vokal seperti a, i, u, e, dan o serta mereka masih kesulitan menggerakkan tangan untuk menulis angka, kalimat serta huruf, 3 (42,8\%) anak sudah bisa memegang pensil tetapi belum sempurna serta mereka masih sedikit kesulitan dalam menggerakkan pergelangan tangan ke atas dan ke bawah, ke kiri dan ke kanan untuk menulis huruf, angka serta kalimat.

Penelitian ini sangat penting dilakukan, karena apabila seorang anak selalu dilatih kemampuan motorik halusnya sejak dini maka anak akan mampu melakukan aktivitas yang berhubungan dengan akademik seperti menulis, menggambar dan mewarnai dan anak juga dilatih menggerakkan jari tangannya agar tidak kaku dalam melakukan aktivitas sehari-hari.

Berdasarkan uraian-uraian diatas maka peneliti berkeinginan untuk meneliti tentang " Pengaruh Terapi Bermain Terhadap Kemampuan Motorik Halus Anak Down Syndrome di SLB YPPLB Padang Tahun 2016“.

\section{METODA PENELITIAN}


Penelitian ini dilakukan dalam bidang kesehatan untuk mengetahui pengaruh terapi bermain terhadap kemampuan motorik halus anak Down Syndrome di SLB YPPLB Padang Tahun 2016. Adapun variabel independen dari penelitian ini pengaruh terapi bermain, sedangkan Variabel dependennya perkembangan motorik halus anak Down Syndrom.

Penelitian dilakukan dari tanggal 08 Mei s/d 28 Mei 2016. Penelitian menggunakan desain penelitian Pre-Eksperimental design (one grup pretest-posttest). Populasi dalam penelitian ini anak Down Syndrome usia sekolah 6-12 tahun berjumlah 13 orang. Sampel penelitian berjumlah 13 orang yang terdiri dari 8 orang laki-laki dan 5 orang perempuan.Teknik pengambilan sampel pada penelitian ini menggunakan teknik sampling jenuh

\section{HASIL}

\section{A. Analisis Univariat}

Tabel 1 Distribusi Rata-Rata Kemampuan Motorik Halus Anak Down Syndrom Sebelum Diberikan Terapi Bermain di SLB YPPLB Padang Tahun 2016

\begin{tabular}{cccccc}
\hline $\begin{array}{c}\text { Kemampuan } \\
\text { Motorik } \\
\text { Halus }\end{array}$ & $\begin{array}{c}\text { Mea } \\
\text { n }\end{array}$ & SD & Min & Mak & n \\
\hline Pre Test & 5,08 & 2,060 & 4 & 9 & 13 \\
\hline
\end{tabular}

Berdasarkan tabel 1 dapat dianalisis distribusi rata-rata kemampuan motorik halus sebelum diberikan terapi bermain 5,08 dengan standar deviasi 2,060, nilai minimum 4 dan nilai maksimum 9 .

Tabel 2 Distribusi Rata-Rata Kemampuan Motorik Halus Anak Down Syndrom Sesudah Diberikan Terapi Bermain di SLB YPPLB Padang Tahun 2016

\begin{tabular}{cccccc}
\hline $\begin{array}{c}\text { Kemampuan } \\
\text { Motorik Halus }\end{array}$ & Mean & SD & $\begin{array}{c}\text { Mi } \\
\mathbf{n}\end{array}$ & Mak & nak \\
\hline Post Test & 12,46 & 3,843 & 4 & 16 & 13 \\
\hline
\end{tabular}

Berdasarkan tabel 2 dapat dianalisis distribusi rata-rata kemampuan motorik halus sesudah diberikan terapi bermain 12,46 dengan standar deviasi 3,843, nilai minimum 4 dan nilai maksimum 16.

\section{B. Analisis Bivariat}

Tabel 3 Perbedaan Rata-Rata Kemampuan Motorik Halus Anak Down Syndrom Sebelum Dan Sesudah Diberikan Terapi Bermain di SLB YPPLB Padang Tahun 2016

\begin{tabular}{cccccc}
\hline Variabel & Mean & SD & SE & P value & N \\
\cline { 1 - 3 } $\begin{array}{c}\text { Kemampuan } \\
\text { motorik }\end{array}$ & & & & & 13 \\
$\quad$ halus & & & & & \\
Pre test & 5,08 & 2,060 & 0,571 & 0,002 & \\
Post test & 12,46 & 3,843 & 1,066 & & \\
\cline { 1 - 4 } Selisih & 7,38 & 1,783 & 0,495 & & \\
\hline
\end{tabular}

Berdasarkan tabel 3 menunjukkan perbandingan kemampuan motorik halus sebelum dan sesudah diberikan terapi bermain, dimana rata-rata kemampuan motorik halus sebelum diberikan terapi bermain 5,08 dengan standar deviasi 2,060 dan sesudah diberikan terapi bermain 12,46 dengan standar deviasi 3,843. Dapat dilihat adanya perbedaan nilai mean antara sebelum dan sesudah diberikan terapi bermain 7,38. Hasil uji statistik didapatkan nilai $\mathrm{P}=0,002$, maka dapat disimpulkan terdapat pengaruh terapi bermain terhadap kemampuan motorik halus anak Down Syndrom di SLB YPPLB Padang Tahun 2016.

\section{PEMBAHASAN}

A. Analisa Univariat

1. Kemampuan Motorik Halus Sebelum Diberikan Terapi Bermain pada Anak Down Syndrome di SLB YPPLB Padang Tahun 2016

Berdasarkan tabel1 dapat dilihat bahwa dari 13 responden sebelum dilakukan intervensi berupa terapi bermain meremas adonan score tertinggi yang didapatkan yaitu 9 dimana kemampuan motorik nhalus anak berkembang sesuai harapan dan score terendah 4, kemampuan motorik halus anak belum 13berkembang dengan rata-rata score kemampuan motorik halus anak Down syndrom sebelum diberikan terapi bermain 5,08.

Hasil penelitian ini sejalan dengan penelitian yang dilakukan oleh Dekayati (2014) dengan judul Pengaruh terapi bermain menyusun menara donat terhadap peningkatan kemampuan motorik halus anak Down Syndrome usia sekolah di SLB Negeri Semarang, dimana perbedaannya hanya pada terapi yang diberikan. Pada penelitian ini peneliti 
memberikan terapi meremas adonan. Hasil penelitian Dekayati (2014) menunjukan kemampuan motorik anak down syndrome sebelum diberikan intervensi terapi bermain menyusun menara donat 21 anak (70\%) tidak mampu. Kemudian setelah diberikan intervensi hasil meningkat sebanyak 16 anak $(53,3 \%)$ mampu.

Saat usia 7 tahun, umumnya anak sudah dapat menulis karena gerakan tangan sudah stabil walaupun kadang belum rapi. Pada usia 8-10 tahun, koordinasi motorik halus berkembang lebih baik lagi dimana anak sudah dapat menulis huruf bersambung. Pada usia 10-12 tahun mereka sudah mampu menunjukkan keterampilan yang lebih kompleks, rumit, dan cepat (Marliani, 2015).

Berbeda dengan anak Down Syndrom, saat usia 6-12 tahun anak mengalami kesulitan melakukan koordinasi antara jari jemari. Anak Down Syndrom disini merupakan anak yang mampu latih, maksudnya yaitu apabila anak Down Syndrom dilatih secara terus menerus akan meningkatkan kemampuan koordinasi gerakan motorik halusnya (Gunarhadi, 2005).

Berdasarkan analisis peneliti sebelum dilakukan terapi bermain meremas adonan kebanyakan anak Down Syndrome di SLB tersebut baru terpapar dengan terapi bermain yang diberikan oleh peneliti, oleh karena itu banyak dari anak Down Syndrome belum mampu untuk melakukan terapi bermain tersebut.

Kemampuan menulis rata-rata anak belum berkembang, dimana hampir sebagian besar anak memerlukan bantuan dalam melakukan terapi. Hal ini terlihat saat dilakukan pre test kemampuan menulis seperti membuat garis vertikal dan horizontal, membuat garis lengkung, membuat lingkaran dan menebalkan angka dan huruf, anak masih dibantu penuh oleh peneliti.

Belum berkembangnya kemampuan motorik halus anak disebabkan berbagai faktor, dimana anak malas untuk menggerakkan jari-jemarinya, anak lebih suka bermain dengan dunianya sendiri, anak kesulitan mengkoordinasikan jari-jemarinya, kurangnya latihan dalam meningkatkan kemampuan motorik halus anak, keterbatasan terapis dalam pemberian terapi, dan lemahnya keadaan daya tangkap anak itu sendiri.

Anak- anak tersebut masih kesulitan untuk mengkoordinasikan gerakan tangannya serta malas untuk menggerakkan jari jemarinya dalam meremas adonan. Hal ini juga terlihat saat anak disuruh menulis, mereka mengalami kesulitan dalam memegang pensil dan menulis apa yang diperintahkan seperti menghubungkan garis vertikal dan horizontal mereka masih memerlukan bantuan.

\section{Kemampuan Motorik Halus Sesudah Diberikan Terapi Bermain pada Anak Down Syndrome di SLB YPPLB Padang Tahun 2016}

Hasil penelitian menunjukkan bahwa dari 13 anak Down Syndrome di Sekolah Luar Biasa (SLB) YPPLB Padang Tahun 2016 didapatkan rata-rata perkembangan kemampuan motorik halus anak Down Syndrom berkembang sangat baik sesudah diberikan terapi bermain, dimana score tertinggi 16 dimana kemampuan motorik halus anak berkembang sangat baik dan score terendah 4 belum berkembang dengan rata-rata score kemampuan motorik halus 12,46.

Hasil penelitian ini sejalan dengan penelitian yang dilakukan oleh Dekayati (2014) dengan judul Pengaruh terapi bermain menyusun menara donat terhadap peningkatan kemampuan motorik anak Down Syndrome usia sekolah di SLB Negeri Semarang, dimana perbedaannya hanya pada terapi yang diberikan. Pada penelitian ini peneliti memberikan terapi meremas adonan, didapatkan hasil bahwa kemampuan motorik halus anak Down Syndrom sesudah diberikan terapi bermain berkembang sangat baik.

Hal ini sesuai dengan teori Janet dalam Anggani (2005) motorik halus adalah gerakan yang dilakukan oleh bagian-bagian tubuh tertentu, yang tidak membutuhkan tenaga besar yang melibatkan otot besar, tetapi hanya melibatkan sebagian anggota tubuh yang dikoordinasikan (kerja yang seimbang) antara mata dengan tangan atau kaki. Tujuan dari melatih motorik halus adalah untuk melatih anak agar terampil dan cermat menggunakan jari- jemari dalam kehidupan sehari-hari, dimana semakin anak dilatih maka kemampuan motoriknya bisa semakin meningkat.

Anak-anak dengan Down Syndrom, mengalami keterlambatan reaksi postural yang berlangsung dengan keterlambatan perkembangan motorik. Oleh karena itu, sangat penting jika diberikan terapi yang dapat meningkatkan rangsangan reaksi postural. Anak Down Syndrome yang mengalami keterlambatan motorik jika diberikan program terapi yang tepat akan dapat meningkatkan reaksi motorik yang baik (Halley, 2008).

Berdasarkan analisis peneliti, dapat disimpulkan bahwa peningkatan perkembangan kemampuan motorik halus anak Down Syndrome di Sekolah Luar Biasa (SLB) YPPLB Padang Tahun 2016 karena 
pemberian waktu terapi yang terus-menerus, pemberian terapi yang individual kepada anak Down Syndrome, serta didukung oleh pendekatan yang sesuai untuk anak Down Syndrome dan lingkungan yang nyaman untuk pemberian terapi.

Hal ini terlihat saat dilakukan pre test kemampuan menulis seperti membuat garis vertikal dan horizontal, membuat garis lengkung, membuat lingkaran dan menebalkan angka dan huruf, anak mampu membuat garis vertikal dan horizontal dengan rapi dan sesuai dengan perintah. Begitu juga dengan membuat garis lengkung, membuat lingkaran dan menebalkan angka dan huruf anak mampu menulis dengan rapi, sesuai perintah dan mandiri tanpa bantuan. Namun, dari hasil penelitian ini juga masih ada sebagian kecil anak Down Syndrome yang rendah perkembangan motorik halusnya dikarenakan lambatnya daya tangkap anak itu sendiri.

\section{B. Analisa Bivariat}

\section{Pengaruh Terapi Bermain Terhadap Kemampuan Motorik Halus Anak Down Syndrom Di SLB YYPLB Padang Tahun 2016}

Berdasarkan hasil penelitian didapatkan bahwa terdapat perbedaan rata-rata perkembangan motorik halus sebelum diberikan terapi bermain adalah 5,08 dan sesudah diberikan terapi bermain didapatkan rata-rata tingkat perkembangan motorik halus anak Down Syndrome meningkat menjadi 12,46. Berdasarkan analisa uji wilcoxon diperoleh nilai $p=$ 0,002 artinya ada pengaruh terapi bermain terhadap kemampuan motorik halus anak Down Syndrom.

Hasil penelitian ini sejalan dengan penelitian Dekayati (2014) Kemampuan motorik halus anak Down Syndrome terdapat peningkatan diperoleh data sebelum diberikan terapi menara donat anak yang mampu sebanyak 9 anak $(30 \%)$ dan setelah diberikan terapi bermain anak yang mampu menjadi sebanyak 16 anak $(53,3 \%)$.

Hasil penelitian ini juga sejalan dengan penelitian Budiman (2008) menunjukkan rata-rata kemampuan motorik anak down syndrome sebelum diberikan alat permainan edukatif (APE) adalah 0,7681 dan sesudah diberikan alat permainan edukatif (APE) adalah 2,4783. Nilai signifikasi yang didapat adalah 0,000 atau > P Value 0,05.

Bermain merupakan suatu aktivitas dimana anak dapat melakukan atau mempraktikkan keterampilan, memberikan ekspresi terhadap pemikiran menjadi kreatif, mempersiapkan diri untuk beperan dan berprilaku dewasa serta memberikan stimulasi dalam kemampuan keterampilan, kognitif, dan afektif dalam membantu perkembangan motorik anak (Soetjiningsih, 2013).

Hal ini sesuai dengan teori Supartini (2004) yaitu kegiatan bermain sangat efektif dilakukan untuk memantau tingkat perkembangan anak. Selain itu saat melakukan permainan, aktifitas sensorik dan motorik merupakan komponen terbesar yang digunakan anak dalam bermain aktif sangat penting untuk perkembangan fungsi otot. Dengan dengan bermain mampu meningkatkan perkembangan kemampuan motorik halus anak.

Berdasarkan pengamatan peneliti tentang pengaruh terapi bermain terhadap perkembangan motorik halus anak Down Syndrome bahwa terapi bermain berpengaruh dalam perkembangan motorik halus anak Down Syndrome jika diberikan secara berkesinambungan, terus-menerus dan pendekatan yang tepat dengan anak. Adanya peningkatan kemampuan motorik halus anak Down Syndrom ini di pengaruhi oleh beberapa faktor diantaranya faktor usia, jenis kelamin dan kelas anak.

Anak Down syndrom yang berusia 12 tahun lebih matang kemampuan motorik halusnya dibandingkan dengan anak usia 7 tahun. Hal ini dilihat dari score kemampuan motorik halus yang diperoleh anak usia 12 tahun adalah 16 berkembang sangat baik sedangkan anak usia 7 tahun hanya memperoleh score 8 mulai berkembang.

Kelas anak juga mempengaruhi peningkatan kemampuan motorik halus anak, semakin tinggi kelas anak semakin baik pula kemampuan motorik halusnya karena anak yang berada dikelas III sudah mendapatkan latihan yang cukup lama dibandingkan anak yang berada dikelas I. Hal ini dapat dilihat dari score yang diperoleh anak kelas III adalah 16 sedangkan anak yang berada dikelas I hanya memperoleh score 4.

Namun dalam penelitian ini juga ditemukan 1 orang anak yang berada dikelas I tidak mengalami perkembangan motorik halus sesudah diberikan terapi bermain, hal ini dikarenakan kurangnya daya tangkap anak itu sendiri serta kurangnya keinginan anak untuk mengikuti terapi yang diberikan oleh peneliti, anak lebih suka melakukan akivitas yang disukai.

Untuk anak Down Syndrom yang berada dikelas III mengalami perkembangan motorik halus yang berbeda-beda, dimana 3 orang anak mampu menulis dengan baik, rapi, sesuai perintah dan tanpa bantuan dan memperoleh score 16 sedangkan 2 orang anak lagi masih belum rapi dalam menulis sehingga hanya 
memperoleh score 12-14. Peningkatan kemampuan motorik halus anak-anak tersebut dipengaruhi oleh beberapa faktor seperti kurangnya latihan yang diberikan kepada anak, lemahnya kemampuan otot anak untuk menggerakkan tangan dan jari-jemari.

Dalam hal ini dapat dilihat terapi bermain mempunyai kontribusi dalam peningkatan perkembangan motorik halus anak Down Syndrome. Dimana tujuan terapi bermain adalah anak dapat mengembangkan kreatifitas dan meningkatkan kekuatan gerakan jari jemari serta meningkatkan kemampuan koordinasi antara mata dan tangan. Diharapkan untuk terapi yang berkelanjutan dan terus menerus maka responden dapat mengembangkan kemampuan motorik halusnya untuk aktivitas kehidupan sehari-hari.

\section{KESIMPULAN}

Berdasarkan hasil penelitian yang telah dilakukan peneliti tentang pengaruh terapi bermain terhadap kemampuan motorik halus anak Down Syndrom di SLB YPPLB Padang, dapat disimpulkan sebagai berikut:

1. Rata-rata kemampuan motorik halus anak Down Syndrom sebelum diberikan terapi bermain adalah 5,08, standar deviasi 2,060 nilai minimum 4 dan nilai maksimum 9 .

2. Rata-rata kemampuan motorik halus anak Down Syndrom sesudah diberikan terapi bermain adalah 12,46, dengan standar deviasi 3,843, nilai minimum 4 dan nilai maksimum 16.

3. Terdapat pengaruh terapi bermain terhadap kemampuan motorik halus anak Down Syndrom sebelum dan sesudah diberikan terapi bermain dengan nilai $p 0,002$.

\section{DAFTAR PUSTAKA}

Acep, Yoni. 2010. Menyusun Penelitian Tindakan Kelas, Yogyakarta: Familia.

Adriana, Dian. 2011.Tumbuh Kembang \& Terapi Bermain Pada Anak, Jakarta: Salemba Medika.

Aryanto. 2008. Gambaran Tentang Proses Pembelajaran Musik Bagi Anak Down Syndrom di Taman Musik Dian Indonesia. Jurnal Universitas Pendidikan Indonesia.

Budiman. 2008.Pengaruh Penggunaan Alat Permainan Edukatif Terhadap Kemampuan Motorik Anak Down Syndrom di SLB B \& C Pambudi Dharma 2. Cimahi: Jurnal Universitas Jendral Ahmad Yani Cimahi.

Chalidah, Ellah Siti. 2005.Terapi Permainan Bagi Anak Yang Memerlukan Layanan Pendidikan Khusus, Jakarta: Departemen Pendidikan Nasional Direktorat Jendral Pendidikan Tinggi.

Dekayati, Silviana, et.al. 2014.Pengaruh Terapi Bermain Menyusun Menara Donat Terhadap Peningkatan Kemampuan Motorik Anak Down Syndrom Usia Sekolah di SLB Negeri Semarang. Jurnal Keperawatan dan Kebidanan, Vol. 1, No 5, 1- 9.

Fadhli, Aulia. 2010.Buku Pintar Kesehatan Anak, Yogyakarta: Pustaka Anggrek.

Gunarhadi. 2005.Penanganan Anak Sindrom Down dalam Lingkungan Keluarga dan Sekolah, Jakarta: Departemen Pendidikan Nasional Direktorat Jendral Pendidikan Tinggi.

Haley. 2008.Down Syndrome: sensory integration, vestibular stimulation and neuro developmental therapy approache for children http://google.com//. Down Syndrome: sensory integration, vestibular stimulation and neuro developmental therapy approache for children Diperoleh tanggal 20 Januari 2016. Pukul 10.00 wib.

Hidayat, Alimul A.A. 2008.Pengantar Ilmu Kesehatan Anak Untuk Pendidikan Kebidanan, Jakarta Selatan: Salemba Medika.

Hurlock, B. Elizabeth. 2001.Perkembangan Anak, Jakarta: Penerbit Erlangga.

Malino, Yulius. 2013. Tumbuh Kembang Anak Cetakan II, Jakarta: EGC

Marliani, Rosleny. 2015.Psikologi Perkembangan, Bandung: CV Pustaka Setia. 
Narendra, Moersintowati B \& dkk. 2010. Tumbuh Kembang Anak Dan Remaja, Jakarta: CV Sagung Seto.

Nasution. 2011. Tindakan Yang Dilakukan Orang Tua Dengan Anak Down Syndrome. Skripsi. Fakultas Ilmu Sosial dan Ilmu Politik Universitas Sumatera Utara (Tidak dipublikasikan).

Nevid, Jeffrey, S \& dkk. 2005.Psikologi Abnormal, Jakarta: Penerbit Erlangga.

Notoatmodjo, S. 2010. Metodologi Penelitian Kesehatan, Jakarta: PT Asdi Mahasatya.

Notoatmodjo, Soekidjo. 2005.Metodologi Penelitian Kesehatan, Jakarta: Rineka Cipta.

Nursalam. 2008. Konsep dan Penerapan Metodologi Penelitian Ilmu Keperawatan, Pedoman Skripsi, Tesis, dan Instrumen Penelitian Keperawatan, Jakarta Selatan: Salemba Medika.

Papalia, Diane E, Olds, Sally W \& Fieidlmean, Ruth D. 2008.Human Development (11th ed.). New York: McGraw-Hill.

Riyadi, Sujono \& Sukarmin. 2013. Asuhan Keperawatan Pada Anak, Yogyakarta: Graha Ilmu.

Santrock, J. 2007.Perkembangan Anak, Edisi ke Sebelas Jilid I, Jakarta: Penerbit Erlangga.

Situmorang, Charina. 2011. Hubungan Sindroma Down dengan Umur Ibu, Pendidikan Ibu, Pendapatan Keluarga, dan Faktor Lingkungan. Jurnal Kedokteran Indonesia, 2(1), 96-101.

Soetjiningsih, Christiana Hari. 2012.Perkembangan Anak Sejak Pertumbuhan Sampai Dengan Kanak-Kanak Akhir, Jakarta: Penerbit Prenada Media Group.

Soetjiningsih \& dkk. 2013.Tumbuh Kembang Anak Cetakan II, Jakarta: EGC.

Sulistyawati, Ari. 2014.Deteksi Tumbuh Kembang Anak, Jakarta Selatan: Salemba medika.
Suriadi \& Yuliani, Rita. 2010.Asuhan Keperawatan Pada Anak, Jakarta: CV Agung Seto.

Sugiyono. 2005.Statistika Untuk Penelitian, Bandung: Alfabeta.

Supartini. 2004.Konsep Dasar Anak, Jakarta: EGC.

Upton, P. 2012. Psikologi Perkembangan, Jakarta: Penerbit Erlangga.

Wardani, IG.A.K \& dkk. 2010. Pengantar Pendidikan Luar Biasa, Jakarta: Universitas Terbuka.

Wong, Donna L., et al.2008.Buku Ajar Keperawatan Pediatrik, Jakarta: Buku Kedokteran EGC. 